\title{
Managerial risk-taking in international acquisitions in the brewery industry: Institutional and ownership influences compared
}

\author{
Abstract \\ This paper deals with the role institutional differences play in managerial risk-taking \\ when engaging in international acquisitions. We assume that MNCs have different \\ interests and capabilities when dealing with international acquisition, which in our \\ view are significantly shaped by specific home country institutional influences. Our \\ study concerns the question of how different forms of ownership - concentrated (e.g. \\ family and bank based) and dispersed (stock market based) - influence risk-taking \\ and managerial decision making in large international acquisitions. Comparing a total \\ of 12 large acquisitions of four leading MNCs in the global brewery industry, the \\ paper shows that mutually reinforcing influences of country of origin (coordinated vs. \\ liberal market economies), and ownership (family ownership vs. stock market \\ ownership) lead to different risk profiles and managerial risk-taking with regard to \\ international acquisitions.
}

\section{Key words}

Multinational corporations, brewery industry, mergers and acquisitions, risk-taking, country-of-origin institutional influences, ownership influences 


\section{Introduction}

Mergers and Acquisitions (M\&As) are an important and much researched aspect of corporate behaviour since they permit firms to utilize opportunities otherwise not available to them under normal operational parameters. Typically they can provide a series of benefits such as technological acquisition, market share increases, scale economies, access to distribution channels, vertical and horizontal integration and even diversification (Ahuja and Katila, 2001; Trautwein, 1990). However, since many M\&As do not succeed (Sirower, 1997) there has been a tendency to seek out specific aspects of such failure rather than see it as a result of more complex integration problems. By examining the initial context and drivers of change that provide the motivation behind such strategies, it is possible to evaluate outcomes and consider the role played by institutional features of the acquiring firm's home country in the shaping of such behaviour. This is especially important when considering international activities by firms.

This paper examines the role institutional differences of coordinated versus liberal market economies, and simultaneously the effect of ownership patters, play in managerial risk-taking when engaging in international acquisitions. We assume that multinational corporations (MNCs) have different interests and capabilities when dealing with international acquisitions, which are, in our view, significantly shaped by specific home country institutional influences of the acquiring firm. Our study investigates how different forms of ownership influence risk-taking and managerial decisions about international acquisitions of four major players in the global brewing industry. 
The brewing industry has undergone considerable consolidation over the past decade as firms have dealt with static domestic markets, intense rivalry in key overseas markets, and opportunities for expansion in emerging markets. In the 1990s the industry changed from being primarily domestic oriented or focusing on low commitment internationalization strategies such as export and licensing, to be very concentrated and truly global (Lopes, 2007). In the last decade international acquisitions have increased significantly across the industrial sector and to some degree they replace the strategy of forming joint ventures with local partners (ibid). However, given the larger commitment and the amount of resources involved, acquisitions are seen as both financially and politically more risky than other entry modes (see e.g. Barkema and Vermeulen, 1998). The influence of the wider society on these strategic decisions, such as home country institutional differences and how they affect acquisition behaviour are often neglected or viewed in a deterministic way that eliminates managerial agency. Similarly, discussion of how risk is assessed is viewed as either an expression of changing strategic initiatives (new management or a reaction to dramatic changes in market activity) or the manifestation of a longstanding propensity that is culturally embedded. Both tend to oversimplify the interaction of key processes or the role of imitative behaviour that can occur.

This paper argues that acquisition risk is conditional upon institutional features as well as firm ownership structure. By differentiating risk according to key firm characteristics we are able to show how overlapping and reinforcing institutional impacts make a clear difference in shaping risk-taking in large acquisitions. Our paper, therefore, focuses on an issue which has not been systematically explored so 
far: the comparison of strategic decisions behind large international acquisitions and the role of managerial risk-taking. In order to understand and assess differences in managerial risk-taking, we refer to national specific institutional features of the acquiring company and compare how features of home country specific financial systems influence risk profiles and risk-taking within MNCs. We compare four MNCs that are in the same industrial sector, two originating from liberal market economies with large domestic markets for beer and two originating from coordinated market economies with a small home market.

\section{Analysing acquisition risk-taking: an eclectic review of the literature}

\subsection{Acquisition risks}

Acquisitions are in general risky investments compared to other types of market entry such as export, licensing and strategic alliances, as they require a higher level of financial investment. Even compared to greenfield establishments, they incur greater risk due to the high premiums often paid for the target firm. High premiums put further risks on non-reversible investments, such as low divestment price of target firms (Brouthers and Dikova, 2010). Our first assessment criterion for acquisition risk is, therefore, the premium paid in relation to the share price of the target firm.

The second criterion of acquisition risk is the relative size of the target firm, in terms of amount and quality of resources, in relation to the acquiring firm and the latter's ability to capitalize on the target firm resources. From a resource-based point of view, Penrose's (1959) growth theory predicts that current acquisitive growth is an outcome of previous organic and acquisitive growth. Companies are (or should be) constrained 
by their amount and quality of resources, where past investments are likely to lead to path dependencies in future strategic action (Teece et al., 1997). Brouthers and Dikova (2010) express this situation as strategic flexibility, which is provided by past investment in human resources, information systems, financial structures, etc. Hoffmann and Schaper-Rinkel (2009) also find that external growth strategies require internal resources, particularly capital and management capacity. Lockett et al. (2011) emphasize that growth constraints are due to adjustment cost, which is the time and efforts used in integrating new managers and operations in expanding the activities of the firm. Further, Nooteboom (1999) emphasizes the need to be able to transfer resources to the 'weak' acquired firm in the form of managers, management systems, knowledge, capital and so forth, in order to replace or renew the consolidated practices of the target firm. The ability to reveal ex-ante synergy opportunities therefore relies on the amount and quality of the acquiring company's resources.Acquisitions of relative large target firms are assessed to be risky when the acquiring company does not have the right amount and quality of resources in place.

An aspect omitted from our analysis is the cultural distances between acquiring and acquired firms. Even though cultural mis-match has been associated with high failure rates of M\&A (Larsson and Finkelstein, 1999), cultural distance has also proven to enhance performance, as acquisitions provide access to valuable pools of critical embedded resources and practices otherwise not available to the acquiring firm (Morosoni et al., 1998). Cultural distance is, therefore, not an acquisition risk per se, but rather an obstacle to reveal ex ante synergies - an obstacle than can be solved by the integration strategy (Schweizer, 2005). 


\subsection{Influences of institutions: home country and ownership patterns}

Acquisition risks can also be assessed from an institutional point of view, although this has been done in a rather limited manner so far (Dunning, 2009). Mainly it is in reference to the structure and size of the domestic market and their influence on internationalization approaches of firms as well as the role of national industrial policies for the internationalisation of R\&D activities (Narula, 2000). What has often been ignored is how different kinds of societal institutions govern business activities in ways that encourage firms to develop capabilities that enhance their competitiveness in new and different markets (Whitley, 2007). Similarly are there circumstances that inhibit foreign acquisition risk-taking? In an attempt to clarify and address this question we distinguish between coordinated and liberal market economies, and relate this to the division between family and concentrated ownership.

\subsubsection{Coordinated versus liberal market economies}

The role of home country national institutions has only briefly been considered in international management research as being critical to the analysis internationalization strategies (Noorderhaven and Harzing, 2003). The key question here is how differences between societal institutions (e.g. the political, financial, educational and industrial relations systems) influence acquisition strategies of MNCs. It is assumed that national specific institutional characteristics are reflected in strategic managerial decision processes of the MNC because of these actors' socialisation and social embeddedness within their home country society and culture. Implicit here is an understanding of culture whereby shared beliefs and attitudes about what is 
appropriate to do in particular circumstances is paramount (Hall and Soskice 2001, Whitley 1999).

Using a comparative institutionalist perspective we distinguish between two significantly different systems: bank-based financial systems that are typical for coordinated market economies such as Denmark and the Netherlands and marketbased financial systems that are typical for liberal market economies such as the UK and the USA (Aguilera and Jackson, 2003). Both types of market economies match very well with underlying cultural differences such as collectivism/individualism (Hofstede 1980') In contrast to liberal market economies, capital markets in coordinated market economies are less developed, and concentrated forms of ownership are institutionally supported. In coordinated economies banks use ownership stakes to pursue the strategic interests of their clients (firms), compared to shareholders who mainly follow financial interests in order to increase the market value of shares (ibid). The strategic approach of stock market listed firms is often more narrowly focused on financial control of assets; the approach of the latter, however, is much more broadly focused on the company's long-term growth (ibid). In sum, financial systems in coordinated market economies are characterised as more deeply socially embedded in the national business system with so-called relationship banking a common practice (Whitley, 1999). This is opposite to companies that have arm lengths relations with banks in liberal market economies, such as the UK or the US. Relationship banking means that banks are strongly involved in lending, supporting long-term commitment which involves having 'softer' measures in place for firms that under-perform or have short-term financial problems (see also Geppert and Martens, 2009). 
These home country specific institutional differences are mirrored in the beer industry as seen in Table I. One can see that the British brewery Scottish and Newcastle (S\&N) increased its stock market based investments to finance its acquisitions investments abroad. Furthermore, Anheuser Bush (A-B) of the US has the highest degree of stock market reliance. In comparison, the influence of bank based corporate financing of the two MNCs from coordinated market economies (Heineken, the Netherlands, and Carlsberg, Denmark) is significantly higher.

Table I about here

\subsubsection{Family versus stock market based ownership forms}

Intitutionalist approaches often suffer from the problem of 'oversocialized' agency, leaving no room for strategic choice and managerial decision making (Child, 1972). Dealing with this problem, Aguilera and Jackson (2003) propose an 'actor-centred' institutionalist framework that captures the interconnectedness of managerial strategies and societal constraints. Accordingly, it is assumed that societal institutions of liberal market economies encourage 'autonomy' 'to make tough decisions' or to impose hierarchical control in the firm' (ibid, p. 457). Managers in coordinated market economies, however, are seen as more 'committed' because they are dependent on 'firm specific relationships' to owners (ibid, p. 458), which includes banks and families as well as other important stakeholders such as employees and trade unions. These institutional pressures, therefore, affect ownership patterns in the coordinated and liberal market economies. Family ownership is often treated as a "form of European exceptionalism or a political and institutional reluctance to follow 
the U.S. path of modern capitalism" (James, 2008, p. 1), despite the fact that family firms are far more common around the world, including in the UK and US and especially in certain sectors, as the brewery industry.

There has been an extensive debate as to whether family owned or stock market listed firms are more efficient and better business models. Some argue that the dominance of the family leads to agency problems, such as poor management and inefficient internationalization approaches (Fernández and Nieto, 2006); others challenge agency theory by showing that managers of family firms seem to be better equipped than managers of stock market listed firms to develop sustainable and entrepreneurial management concepts (Zahra, 2003). Our research concurs with Lopes' (2007) study on the alcoholic beverage industry (spirits, wine and beer) which is consistent with the latter argument stressing that family firms are adept at balancing entrepreneurship with professional management and thus better equipped to take advantage of strategic opportunities than their stock market listed counterparts.

\subsection{Research Assumptions}

Capturing this interconnectedness between home country institutional influences, ownership patterns and managerial risk-taking, our paper assumes the following:

(1) MNCs originating in coordinated market economies tend to have lower risk profiles and apply a more cautious managerial risk-taking approach when it comes to large international acquisitions and post-acquisition strategies. In comparison, managerial risk-taking is higher in MNCs originating in liberal market economies because there is stronger pressure for short-term profits (as 
indicated by quarterly financial reports) since depressed earnings can lower share prices. Conversely, family owned companies are far less likely to be subject to this pressure as long as owners view short term negative performance as a trade off for longer term financial viability.

(2) Concentrated ownership forms, based on closer social relationships between controlling shareholders, such as banks and families, institutionally support the development of a more moderate risk profile. We believe that concentrated ownership reinforces this tendency, leading to more cautious managerial risktaking in the case of international acquisitions.

(3) Risk profile and managerial risk-taking are high when MNCs pay higher premiums for international acquisitions and when the acquiring firm's pool of resources is likely to constrain an effective integration process and limit the capitalization of ex-ante synergies.

\section{Methodology}

Utilising a case study approach, this paper analyses managerial risk-taking in the international acquisition strategies of global breweries. A comparative setting was chosen to increase variance and divergence in data aiming at a better understanding of the specific mechanisms of managerial risk-taking in firms originating from systematically different institutional contexts (Eisenhardt, 1989; George and Bennett, 2005). Based on the national business systems approach (Whitley, 1999) two firms from coordinated market economies (Heineken and Carlsberg) and two firms originating from liberal market economies (Anheuser-Busch (A-B) and Scottish \& Newcastle $(\mathrm{S} \& \mathrm{~N}))$ were selected. 
For each of these companies, three large foreign acquisitions that took place between the early 1990s and 2006 were selected (see table II). Moreover, in each case, the three acquisitions considered represent a large part of the increase in multinationality that these companies have undergone between 1990 and $2006^{\mathrm{ii}}$. The final selection on what large acquisitions to study was determined by data availability. The year 1990 has been chosen as starting point for our research as the early 1990s are seen as a phase in which the acquisitions of brewery companies started to intensify (BensonArmer et al., 1999; Lopes, 2007). The year 2006 was taken as an end to allow an assessment of post-acquisition integration.

Data on acquisitions was compiled from multiple secondary sources. One source was the 2008 Thomson Financial Extel Company reports, listing the largest acquisitions a company has undertaken from 1990 till 2006 with information on deal date, deal value, shares bought and shares held. This information was cross checked and substantiated by information given on large acquisitions in the 'History section' of the corresponding 2008 company profiles of Datamonitor. Inconsistencies between the two sources were clarified by information provided in business newspapers and magazines. Business and newspaper magazine articles also served as an independent data source providing information on the risk associated with individual acquisitions as well as on the post-acquisition integration process. They were systematically accessed by Lexis-Nexis press retrieval services as well as by visits in the HWWA press archive. ${ }^{\text {iii }}$ In addition to numerous newspaper and magazine articles covering strategic and organizational issues on the four firms studied, selected information 
from the companies (mostly annual reports) as well as from secondary sources (e,g. Elshof, 2004; Ebneth and Theuvsen, 2007; Dieng et al., 2009) was included.

A focus on published secondary data was pursued to avoid strategically manipulative answers that might have been obtained for instance by interviewing company officials on critical issues such as acquisition risks or expected synergies (cf. Salancik and Meindel, 1984). Typical problems that occur when using published secondary sources were carefully dealt with: in this instance following Scott's (1990) approach by critically assessing the authenticity, credibility, representativeness and the meaning of each document used. Based on this evaluation, 12 draft cases on individual acquisitions were developed by the authors. Using the concept of investigators triangulation (Houman-Anderson and Skaates, 2004) each co-author was searching for within-case and across-case patterns, with the individual results being discussed and consolidated in two meetings. Finally, the result of our analysis was validated in interviews with company representatives and industry experts.

\section{Cross-case and -country comparisons}

As posited above we expect that the mutually reinforcing influences of country of origin (coordinated vs. liberal market economies) and ownership (family ownership vs. stock market ownership) lead to different risk profiles and managerial risk-taking with regard to international acquisitions. Thus, we assume Heineken and Carlsberg, as two family owned breweries from coordinated market economies that have been pioneers in internationalizing, to operate with a much lower risk profile than A-B and S\&N, two stock-market listed companies from large liberal market economies that 
have tried to catch up in internationalization through acquisitions. We also expect that higher risk profiles are linked with resource constraints, which consequently leads to increased managerial risk-taking in related company cases.

Our analysis focuses on different aspects of acquisition risk-taking, which is: 1) the premium paid for the target firm, 2) ownership influences, and 3) the resource related growth constraints of the firms.

\subsection{Target firm premium}

The premium paid for the target firm is related to the investment risk of the acquisition. The higher the premium being paid, the higher the synergy effects required to make the investment profitable. As a research assumption, we expect that Heineken and Carlsberg would have paid lower premiums than A-B and S\&N.

Table II about here

Looking at the financial data given in table II, which provides a brief overview on the acquisition cases included in our study, the assumption above is supported. On a comparative basis, A-B and S\&N paid significantly more for their large acquisitions than Heineken and Carlsberg. Heineken paid on average 1.99 times the multiple of sales (based on data for 3 large acquisitions) whereas Carlsberg only paid 1.30 times the multiple of sales (based on data for 2 large acquisitions). This compares to an average of 2.64 times the sales paid in large deals by S\&N and 2.60 by A-B (based on data of each 3 large acquisitions). A similar but somewhat less striking difference 
between the two groups of companies can be found by looking at the relationship between the deal value and the EBITA (or net profit).

In the case of Heineken, market analysis suggests that the price paid for Austrian BBAG was slightly too high. Despite this, analysts unanimously agreed that the company's strategic positioning and cost savings were optimum (Financial Times Deutschland, May 5, 2003). Furthermore, compared to the cost of a typical greenfield establishment in Russia, the price paid by Heineken for Bravo was considered as fair by market analysts (Eliassov, 2002). Regarding Carlsberg's acquisitions, market analysts only reacted on the take-over of German Holsten, assessing it as less promising (Børsen, January 1, 2004; Børsen, February 11, 2004).

However most of the financial press were shocked when $A-B$ announced a hostile takeover bid for Chinese Harbin in 2004. A-B entered a bidding war with SABMiller because it wanted to counter the latter's expansion into China's fast growing beer market (Financial Times, May 17, 2004). The winning bid of $\$ 720 \mathrm{~m}$ was viewed by many as about $\$ 200 \mathrm{~m}$ more than the company was worth with the Economist going so far as calling the bid "irrational"(Economist, June 4, 2004). The bid represented five times Harbin's 2003 sales and about 35 times the EBITA.

The acquisitions made by $S \& N$ were an outcome of its divestment strategy. In response to the constant pressure from analysts and shareholders, S\&N management first divested its leisure business (2000) and subsequently sold its restaurant and pub business (2003). Then, S\&N sold its stake in the holiday centre's business (Center Parcs) at about 30\% below initial price expectations (Frankfurter Allgemeine Zeitung 
March 1, 2000; Börsen Zeitung, November 22, 2000). Nevertheless, the financial leeway gained through these divestures was needed ${ }^{\text {iv }}$ to acquire three large brewery groups abroad in a very short period of time leading to increased premiums paid. The premium paid for French Kronenbourg was comparatively low in relation to the other cases; however the scope for synergies was seen as rather limited, as the Kronenbourg brand is hardly known outside France. Hence, analysts claimed the price as being too high (Financial Times, March 21, 2000). Furthermore, one month later, S\&N acquired a 49\% minority stake in Portuguese Central de Cervejas. In 2003 the remaining 51\% was acquired. The total deal was worth $828 \mathrm{~m} €-3.3$ times the annual sales volume. As some analysts noted, this rather high price is only partly justified by the potential of the well known Sagres brand (Financial Times, May 14, 2003).

\subsection{Ownership influences}

Next we compare differences in risk profile and managerial risk-taking in relation to the differences in ownership structures. We again expect a lower risk profile in the case of family or foundation influence compared to MNCs with dispersed (stock market listed) ownership.

Heineken's cautious acquisition strategy is underpinned by its ownership structure, which gives the Heineken family a 50.005 per cent voting edge. The family in general dislikes large acquisitions that might have negative repercussions on the corporate culture. Family control is considered as "a safeguard to continuity, independence and stability" as well as essential to the "controlled steady growth of the activities of the Heineken group" (Heineken annual report, 2009, p. 160). One example of a cautious acquisition strategy was when Heineken did not engage in the take-over battle for 
$\mathrm{SAB}$ at the end of the 1990s due to the political risks involved. Also financial risks hamper investments abroad. Another example is the wait and see approach Heineken took with regard to the Chinese market, reflecting the overall policy of Heineken to “...not so much look at the volume but at profit" (CEO Jean van Boxmeer in Börsen Zeitung, June 22, 2002) According to Boxmeer "acquisitions are not done at any price" (ibid), but need to quickly contribute to profit and shareholder value.

In the inaugural statement of the Carlsberg foundation, Carlsberg's founder J.C. Jacobsen claimed that the Carlsberg Foundation "forever must own a minimum of $51 \%$ of shares of Carlsberg A/S" (Berlingske Tidende, November 4, 2000). Further, composition of Carlsberg's management board was specific, with an extraordinarily large number of representatives from science and academia (Glamann, 1997). This fact is reflected in the risk profile where up until the second half of the 1990s, Carlsberg had a majority ownership in only eight of the 27 breweries (Iversen and Arnold, 2008). Moreover, it turned out that it was impossible for Carlsberg management to acquire Kronenbourg in 2000, as its owner, Danone, wanted a partpayment in shares which was blocked by the Carlsberg Foundation (ibid.). However, in the late 1990s, stock market analysts started to criticize Carlsberg's rather cautious internationalization strategy and attacked the management board as a board of "aunts" (Jyllands Posten, June 1, 2000). These incidents finally triggered an attitude change at the Carlsberg Foundation. In 2000, the Foundation relinquished its requirement to hold a minimum of $51 \%$ of Carlsberg A/S and the number of representatives from academia in the management board was reduced to one member (ibid.). These changes clearly led to some larger and more risky international investments, such as the 2008 mega-acquisition of S\&N. However, Carlsberg continues to display strong 
risk awareness, reflected in a cautious partial acquisition strategy and a strong drive for efficiency in sourcing, production and distribution by newly acquired subsidiaries abroad. Another example is the fact that in 2002 Carlsberg did not buy Hartwall's share in $\mathrm{BBH}$, of which Carlsberg already owned 50\%. According to an anonymous source in Carlsberg this was due to concerns of the Carlsberg Foundation, which considered entry into the Russian market too risky at this time (Børsen, February 20, 2004).

According to many experts, the rather late and contradictory acquisition strategy of $A$ $B$ is also a testament to struggles for control within the firm, where members of the founding family have historically wielded more power than their shareholdings (approximately $4 \%$ of voting stock) would suggest, and the short-term interests of the capital markets were satisfied for a rather long time from the earnings on the domestic market. The board was conservative over initial overseas expansion, preferring joint ventures. Yet when A-B's major competitors aggressively expanded into emerging markets, the company followed suit, but without an operational coherence other than that of building market share. Such actions were less motivated by shareholder value concerns than they were by an almost visceral response by the family dominated management structure in the St Louis headquarters. In this sense the company's actions were an immediate response to the behaviour of its competitors; a short term view that would have long term financial repercussions. For many in the business press the managerial actions were deemed irrational and fiscally imprudent, but also seen as reflecting the failure of August Busch III to invest significantly overseas when earlier opportunities arose (Wall Street Journal, June 17, 2008). 
In comparison to the other three cases, the acquisition strategy of S\&N was the most open towards the short term profit expectations of analysts and shareholders. This became quite obvious in the firm's behaviour prior to the take-over. Even when the management actively opposed the hostile take-over bid of rivals Heineken and Carlsberg and tried to force Carlsberg legally to sell its stake in BBH to $\mathrm{S} \& \mathrm{~N}$, the $\mathrm{CEO}$, a former City analyst, made it quite clear that - no matter whether S\&N or its rivals will win these 'battles'- "either way our shareholders will benefit" (Financial Times, November 21, 2007). This meant that shareholders and analysts moved increasingly into prominent positions, playing with options to sell $\mathrm{S} \& \mathrm{~N}$ to a number of highly interested competitors. This is reflected in S\&N's management board that has consistently been filled with non-executive directors which no longer saw room for S\&N as an independent global brewer (see e.g. Financial Times, October 18, 2007), leaving the integration of the 3 large acquisitions S\&N had undertaken after the millennium unresolved (see in more detail below). S\&N was indeed one of the few remaining brewers with an open share register and no controlling shareholder in a consolidating sector (The Grocer, October 20, 2007).

\subsection{Resource related risks}

A third aspect of risk-taking in acquisitions is resource related risk that might lead to growth constraints. As discussed earlier, two intertwined factors can make up such growth constraints. The first factor is the amount and quality of resources in the target firm, especially when subsequent substantial investments are needed to increase efficiency and reveal synergy. The second deals with the resources and the experience available at the acquiring firm to deal with such resource mismatch. We will first analyse the cases of Heineken and Carlsberg and show that they took fewer resource 
related risks and that they could draw on strong historical experience in dealing with such risks. This is followed by an analysis of $A \& B$ and $S \& N$, where strong resource related acquisition risks were aggravated by missing resources, political will and experience in dealing with such risks.

All three acquisition targets of Heineken met criteria for efficiently run breweries. With the take-over of Spanish Cruzcampo, Heineken became market leader in Spain with significant future growth potential (The Guardian, June 11, 1999; Heineken annual report, 2007). Moreover, Heineken gained access to the highly valuable market knowledge of BBAG in Central and Eastern Europe: "BBAG are good brewers, and they know the region like nobody else" (CEO of Heineken Tony Ruys cited in Business week online, September 8, 2003). Further, BBAG was considered to be a company with an extremely solid balance sheet and decent management (Financial Times May 3, 2005). Taking over Russian Bravo provided Heineken with a well managed state-of-the-art brewery. Moreover, Bravo had successfully launched a premium brand named Bochkarev (The St. Petersburg Times, February 2, 2002).

Heineken was also an experienced acquirer. It has a long tradition of international full and partial acquisitions and had already reached a high level of internationalization by the 1990s (Dieng et al., 2009). Heineken's experience is demonstrated by the far reaching integration of Cruzcampo, which successfully made its global brands 'Heineken' and 'Amstel' into market leaders in Spain. Moreover, a new very efficient brewery was built in Seville, the first greenfield investment of Heineken in Western Europe in 25 years. The acquisition of BBAG also fit perfectly into the Heineken network of subsidiaries in Central and Eastern Europe (Elshof, 2005). This was 
accompanied by a careful integration policy that initially focused on preserving BBAG activities. None of the Austrian production sites was closed immediately, and closures in Central and Eastern Europe affected both former BBAG and Heineken plants. For example, in Hungary, Heineken's site was closed, whereas Brau Union's two breweries maintained production. Heineken integrated its Central and Eastern European businesses (including Germany, Greece and Russia) into BBAG/Brau Union's existing organizational structure and declared the head-office of Brau Union as the divisional Headquarters of all Heineken activities in Central and Eastern Europe. Finally, in the case of Russian brewery Bravo, Heineken decided to keep the Russian management and continuously undertook follow-up investments. (Heineken Annual Report, 2007).

Despite initial problems, the acquisitions made by Carlsberg were ultimately successful, realizing both synergies and growth. Initially, the investment in Okocim in Poland turned out to be problematic, and Carlsberg experienced a drop in market share from $8 \%$ to $5 \%$. Furthermore, production and distribution at Okocim was rather inefficient and Carlsberg had to spend 70m€ to upgrade the company. (Carlsberg Annual Report, 2006). Declining sales in Switzerland following the acquisition of Feldschlösschen was an outcome of declining sales in the market in general. Holsten, at the time of take-over ranked second in the Northern Germany, and yet was an international player with sales in 90 countries.

Similar to Heineken, Carlsberg has quite a long history of internationalization. They have marketed beer abroad since the $19^{\text {th }}$ century and foreign investments intensified in the 1950s and 1960s. This included greenfield investments in a number of countries 
around the world over the next two decades as well as taking over stakes in small and medium sized foreign breweries (Glamann, 1997). Based on these experiences Carlsberg was able to integrate the three larger acquisitions studied here. Okocim was upgraded through large investments in capacity and modernization of production assets (Carlsberg Annual Report, 2006). Furthermore, the number of production sites had been reduced from four to three, packaging sites from 12 to seven, and warehouses from 12 to six (Koudal and Engel, 2007). The rather successful integration of Okocim is also demonstrated by the fact that it has gained an international mandate despite initial plans of Carlsberg to replace the local brand with Carlsberg's international brands (Meyer and Tran, 2006). Thus the Okocim brand has been launched in the UK (targeting the 600,000 Polish inhabitants in Britain (Grocer, March 11, 2006; Marketing Week, June 28, 2007) and India (Business Today, October, 21, 2007). In respect to Feldschlösschen strong restructuring efforts (e.g., significant investments in production) were made, the number of breweries was reduced, and wine and mineral water businesses were divested. Feldschlösschen soon met the profit standards of successful Carlsberg breweries elsewhere (Jyllands Posten, August 4, 2004). Finally, synergies were soon gained in the case of Holsten through the transfer of Carlsberg best practices in production processes and procurement, combined with the cross selling of Carlsberg and Holsten brands. Further, due to strong reorganisation efforts, such as spinning off the brewery in Mönchengladbach and starting to produce Holsten in the UK, cost efficiency has been reached over time (Børsen, January 23, 2004; Carlsberg Press release, November 10, 2005).

Unlike Heineken and Carlsberg, $A-B$ in the past relentlessly pursued a strategy designed to increase its domestic market share, entering into joint ventures and 
strategic alliances with overseas companies more as a secondary activity. An obsession with domestic market share was perhaps borne out of the sheer size of the US market and the fact that A-B had built up significant brand equity over the past 100 years. However, as price competition intensified and industry concentration in the US increased during the 1980s and early 1990s, A-B was forced to rethink its earlier complacency towards internationalisation. First notable internationalizations however were taken about 100 years later compared to the internationalization of Heineken and Carlsberg. One example of A-B's late internationalization steps is a joint venture between A-B and Japan's Kirin Brewery, formed in 1993 to control marketing, sales and distribution. In a similar vein, a licensing arrangement with Oriental Brewing Company Ltd in Korea allowed A-B premium Brand 'Budweiser' to establish a share in excess of 70 percent of the international beer brands in that country (Anheuser Bush Annual Report, 1993). Later, A-B embarked upon a different international strategy when it acquired a stake in Mexico's leading brewer Grupo Modelo in 1993 and China's largest brewing company, Tsingtao, in that same year. In 2004 it added to this activity by mounting a hostile bid for Harbin, China's fourth largest brewery. These three acquisitions appeared to many in the financial press to be more of a reaction to other major foreign brewers' international strategies than a carefully thought out plan by A-B. While Grupo Modelo made sense given the growth in consumption of its core beers (Corona and Corona Light) in the US and the existing marketing relationship between the two companies, the latter two acquisitions were expensive and contradictory (Harbin and Tsingtao were major competitors with each other) and made in a hyper competitive, cost driven market (Heracleous, 2001). Additionally, it wasn't clear what plans A-B had for the combined company, how the newly acquired assets would fit with its existing relationship with Tsingtao (Financial 
Times, June 29, 2005), and how such risky foreign acquisitions would be integrated and thus create synergies with A-B's core business in the large US home market. Overall, a misfit with regard to the quality of resources in the target companies was accompanied by a lack of strategic foresight and experience in international postacquisition integration.

Originating from a large and protected beer market, it was not before the turn of the millennium that $S \& N$ seriously entered foreign markets (e.g. Lewis 2001). Initially only exporting beer to a limited number of countries, S\&N's internationalization skyrocketed following a few large acquisitions in the early 2000s. With the acquisition of Kronenbourg, S\&N suddenly became the market leader in France. Likewise, the take-over of Hartwall, the joint venture with BBH, gave S\&N access to $30 \%$ of the Russian market. These acquisitions not only displayed on average a higher financial risk than the financial risks taken by Heineken and Carlsberg (see above), but their integration and the creation of synergies turned out to be a problematic management task, exacerbated by the time pressures triggered by short term financial pressures. S\&N management struggled, ultimately unsuccessfully, to absorb these acquisitions. For example, the restructuring and integration of Kronenbourg up until 2003 was rather limited, but intensified in the years that followed (e.g. though plant closures, transfer of production, cost saving programs, and IT integration) (Financial Times, July 2, 2003; Financial Times August 10, 2005). Further, integration of Central de Cervejas into $\mathrm{S} \& \mathrm{~N}$ was rather limited due to an unfolding debate in Portugal on the sale of the country's biggest companies to foreigners. Thus, Central de Cervejas continued to be managed by an independent management team in which Portuguese executives dominated (Financial Times, May 14, 2003). Finally, 
integration of Hartwall remained rather piecemeal, with Carlsberg, a fierce competitor, owning the other half of $\mathrm{BBH}$. Hence, $\mathrm{BBH}$ continued to be managed from Helsinki. In short, like in the case of A-B, S\&N had little experience in international acquisitions leading to weak post-acquisition strategies and difficulties in creating viable synergies between its core business in the home country and the acquired companies abroad.

\section{Discussion}

Table III provides an overview of our key findings. Our initial research assumption that Heineken and Carlsberg display lower risk profiles in large acquisitions abroad than A-B and S\&N is broadly confirmed. We also found some support for the underlying relationship assumptions. The companies from small home countries (Heineken and Carlsberg) internationalized from the outset. Since further growth often was only possible abroad, these firms developed a rather strong position outside their home country over decades. In both cases, the owning family (Heineken) or Foundation (Carlsberg) directly vetoed acquisitions that seemed too risky and made certain that management followed a rather long-term approach, engaging in large take-overs only when they were financially and strategically sound. This due diligence also shows up in their better strategic capability to create synergies between the acquired target firms and other business units of the companies, which was missing in cases of A-B and S\&N. Finally, Heineken and Carlsberg display a much lower reliance on capital markets in their financing than A-B and S\&N (see Table I), thus sheltering managerial risk-taking from short term profit maximizing pressure from capital markets. 
This pressure was most evident in the case of $S \& N$, where management was pushed into a rather high risk strategy with regard to large acquisitions. We found reinforcing influences of the short-termist capital market (home country influence) leading to high 'speed' (Vermeulen and Barkema, 2002) and thus risky large acquisitions which made it difficult for the management to learn and develop the company into a sustainable and independent global player within the beer industry. Our research also confirms the findings of an earlier comparative study on managerial decision-making styles (Axelsson et al., 1991) which stresses that strategic decisions in British firms are made quicker because participants show relatively low commitment, in comparison to their Swedish counterparts. Managerial decision-making in coordinated market environments requires more negotiation, which leads to both longer decision times and stronger managerial commitment.

A-B is the company, with the highest percentage (98.6\%) of shares listed on the stock market of our four cases (see Table I). However, the firm's dominant position in the domestic market and its foray into internationalization largely structured around joint ventures left it somewhat unwilling to recognise the benefits of international acquisitions and then exposed its lack of experience when it finally did commit to such a strategy. Not surprisingly the 'irregularity' of this strategic approach is negatively related to performance, as Vermeulen and Barkema (2002) have argued. However, the effects of the capital market on international acquisition strategies and risk-taking are less clear cut in comparison to $\mathrm{S} \& \mathrm{~N}$. This indicates the moderating role of both the size of the home country market, which makes A-B a late comer in terms of acquiring wholly owned subsidiaries internationally, and that of the founding 
family. A-B's earlier behaviour, where executives were responsive to dominant family members, suggests what Roberts (2004) termed an affliction with hubris and an overestimation of their abilities to run the company. The recent rise of investor activism finally put paid to that modus operandi, with the debacles associated with AB's poorly conceived China strategy exposing the management ineptitude. Unlike family or foundation dominated firms in coordinated economies, A-B's family grip on the company was no match for shareholders seeking to maximise their short term profits when an opportunity arose.

Analyzing the particular risk profiles of the companies, Heineken and Carlsberg show a strong concern for the financial exposure they incur with large acquisitions, carefully select targets aimed at a strategic fit and devote many managerial efforts to the rationalization, modernization and integration of the acquired firms. In comparison, A-B and S\&N played catch-up in internationalization. The result is that they incurred rather high financial risks, missed an optimal strategic fit and overstrained their organizations with a large burden of integration tasks, for which they lacked both experience and capacity.

To sum up, with an increase in the pace of consolidation in the global beer market after the turn of the millennium, including more and more large and very large acquisitions, companies with a strong history of internationalization and a strong influence of family or foundation ownership seem to survive and prosper (Carlsberg and Heineken). In contrast, companies with comparatively little international experience and a rather dispersed ownership $(A-B, S \& N)$ made less fiscally prudent acquisitions and ended up as take-over targets. 


\section{Concluding remarks}

Our paper sheds light on current debates about the future of 'shareholder value capitalism' and the problems firms face if they are highly dependent on capital markets. Comparing the acquisition strategy of four major players in the brewery industry, we found that stock market pressures led to more risky acquisition profiles by MNCs originating from liberal market economies.

Moreover, our research confirms earlier research findings (Lopes, 2007; Lewis, 2001) that successful global players apply a risk-taking approach which carefully combines entrepreneurship and professional management. However, based on the findings of this study we add that this is not only an indicator of the importance of family ownership within this sector, but also of the role of home country specific forms of corporate financing and effective management of resources for the acquiring firm, especially in both the acquisition and the post-acquisition phase.

Our analysis has also shown that eclectic application of conceptual ideas can be a useful approach to analyse the behaviour of management in MNCs. Such an approach has been fruitfully applied earlier by scholars such as Dunning (1988) in the area of international business and Sorge (2005) in the areas of international management and organisation studies. In this paper, in order to analyse and compare the risk profiles and managerial risk-taking practices of MNCs when engaging in large acquisitions, we have combined theories about the role of home country institutions for the acquiring firm, ownership patterns and the resource based view of firms. 
Our findings can also be related to a current debate in the British Journal of Management criticizing mainstream corporate governance research for pointing to a "universal link between corporate governance practices (e.g. shareholder activism, board independence) and performance outcomes, but neglects how interdependences between the organization and diverse environments lead to variations in the effectiveness of different corporate governance practices" (Filatotchev and Nakajima 2010, p. 591). Accordingly, our paper demonstrates why and how national institutional diversity matters in the analysis of the management of international acquisitions. In our study we contribute to the growing body of literature on countryof-origin effects. This research stream has dealt with many different aspects of corporate internationalization such as cross-border management styles (e.g. Dörrenbächer, 2000; Whitley, 2001), management and employment practices (e.g. Ferner, 1997; Geppert et al., 2003) or internationalization patterns (Rugman 2005), but has missed out on looking at acquisitions, which have been observed as the dominant mode of internationalization over the past two decades (UNCTAD 2010).

Next to the fact that the country of origin matters to understand managerial risk-taking in international acquisitions, our paper proved that concentrated ownership patterns have reinforcing effects on managerial risk-taking in MNCs which originate from coordinated market economies to adopt more long-term and sustainable strategies when selecting and integrating newly acquired firms. Our empirical findings reveal significant path-dependencies related to historically grown societal institutions and ownership patterns, especially in the cases of Heineken and S\&N. However, our findings also show the role of social agency. In the cases of A-B and Carlsberg, 
powerful social actors-- the family in the case of A-B and powerful shareholders in the case of Carlsberg -- and their interests had a moderating influence on expected path dependencies. To better elucidate these moderating effects is an issue that goes beyond the scope of this study and requires more in-depth research. Finally, because of the strong oligopolistic structure of the global brewery industry, studying the four leading companies affirms the representative nature of our findings for the global brewery industry. Future research needs to apply our research question in other industries and cross-sectoral comparisons. 
Table I: Aggregation of Funding Types (2003-2007) ${ }^{v}$

5 Yr Averages

$\begin{array}{lllll} & \begin{array}{l}\text { A-B } \\ \text { (USA) }\end{array} & \begin{array}{l}\text { S\&N (UK) } \\ \text { Leineken }\end{array} & \begin{array}{l}\text { Carlsberg } \\ \text { (NL) }\end{array} \\ \text { Loan Capital } & \mathbf{9 8 . 6 1 \%} & \mathbf{5 7 . 8 9 \%} & \mathbf{3 4 . 1 1 \%} & \mathbf{4 5 . 7 5 \%} \\ \text { Bank Loans } & \mathbf{0 . 6 0 \%} & \mathbf{3 1 . 2 7 \%} & \mathbf{4 2 . 3 9 \%} & \mathbf{2 9 . 6 3 \%} \\ \begin{array}{l}\text { Finance leases } \\ \text { Bills and notes }\end{array} & & & & \mathbf{0 . 3 5 \%} \\ \begin{array}{l}\text { Bank Ins and Overdrafts } \\ \text { Mortgages }\end{array} & \mathbf{0 . 3 1 \%} & & & \\ \begin{array}{l}\text { Other Loans } \\ \text { Total }\end{array} & & & & \mathbf{3 . 1 6 \%} \\ & \mathbf{0 . 4 9 \%} & \mathbf{3 . 4 4 \%} & \mathbf{7 . 7 5 \%} & \mathbf{5 . 0 6 \%} \\ & \mathbf{1 0 0 . 0 0 \%} & \mathbf{1 0 0 . 0 0 \%} & \mathbf{1 0 0 . 0 0 \%} & \mathbf{1 0 0 . 0 0 \%}\end{array}$

Sources: Thomson Financial Extel Company reports 2008 
Table II: Large acquisitions of Heineken, Carlsberg, Anheuser Busch and Scottish \& Newcastle compared

\begin{tabular}{|c|c|c|c|c|c|c|c|c|}
\hline & Year & $\begin{array}{l}\text { Shares } \\
\text {-bought } \\
\text {-owned }\end{array}$ & $\begin{array}{l}\text { Trans- } \\
\text { action }(T) \\
\text { Value } \\
(\mathbf{m})\end{array}$ & $\begin{array}{l}\text { Sales } \\
\text { volume } \\
\text { mhl }\end{array}$ & $\begin{array}{l}\text { No. of } \\
\text { Empl- } \\
\text { oyees }\end{array}$ & $\begin{array}{l}\text { T-value as } \\
\text { multiple of } \\
\text { Sales (1) }\end{array}$ & $\begin{array}{l}\text { T-value } \\
\text { as } \\
\text { Multiple } \\
\text { of } \\
\text { EBITDA } \\
\text { (1) } \\
\end{array}$ & $\begin{array}{l}\text { T Value } \\
\text { as } \\
\text { Multiple } \\
\text { of hl } \\
(€ / h l)(1)\end{array}$ \\
\hline \multicolumn{9}{|l|}{ Heineken (NL) } \\
\hline $\begin{array}{l}\text { Cruzcampo (ES) } \\
\text { (3) }\end{array}$ & 2000 & $\begin{array}{l}88.2 \\
88.2\end{array}$ & $650 \mathrm{m€}$ & 6 & 2200 & $1.81(2)$ & n.a. & $113(2)$ \\
\hline $\begin{array}{l}\text { BBAG /Brau } \\
\text { Union (AU) }\end{array}$ & 2002 & $\begin{array}{l}100 \\
100\end{array}$ & $1899 \mathrm{m€}$ & 16 & 7080 & 1.73 & 10.2 & 146 \\
\hline Bravo (RUS) & 2002 & $\begin{array}{l}100 \\
100\end{array}$ & $395 \mathrm{m€}$ & 2.9 & 1600 & 2.43 & 9.7 & 137 \\
\hline \multicolumn{9}{|l|}{ Carlsberg (DK) } \\
\hline Okocim (PL) & $\begin{array}{l}1996 / \\
2000\end{array}$ & $\begin{array}{l}100 \\
100\end{array}$ & n.a. & n.a. & ca. 1300 & n.a. & n.a. & n.a. \\
\hline $\begin{array}{l}\text { Brauerei } \\
\text { Feldschloesschen } \\
(\mathrm{CH})\end{array}$ & 2000 & $\begin{array}{l}100 \\
100\end{array}$ & $574 \mathrm{m€}$ & 2,4 & 2600 & 1.60 & 8.6 & 99 \\
\hline Holsten (GER) & 2004 & $\begin{array}{l}100 \\
100 \\
\end{array}$ & $437 \mathrm{m€}$ & n.a. & 1500 & 0.99 & 9.1 & 71 \\
\hline \multicolumn{9}{|l|}{$\begin{array}{l}\text { Anheuser-Busch } \\
\text { (USA) }\end{array}$} \\
\hline $\begin{array}{l}\text { Grupo Modelo SA } \\
\text { de CV (MEX) (5) }\end{array}$ & $\begin{array}{l}1993 / \\
1997 \\
\end{array}$ & $\begin{array}{l}50.2 \\
50.2 \\
\end{array}$ & $1600 \mathrm{~m} \$$ & 35.4 & 41149 & $1.6(2)$ & $11(2)$ & $86.9(2)$ \\
\hline $\begin{array}{l}\text { Tsingtao Brewery } \\
\text { Co. Ltd. (CHN) }\end{array}$ & 2002 & $\begin{array}{l}23.6 \\
27\end{array}$ & $181.6 \mathrm{~m} \$$ & 25 & n.a. & $1.2(2)$ & n.a. & n.a. \\
\hline $\begin{array}{l}\text { Harbin Brewery } \\
\text { Grp Ltd. (CHN) (4) }\end{array}$ & 2004 & $\begin{array}{l}100 \\
100 \\
\end{array}$ & $720 \mathrm{m \$}$ & n.a. & 8000 & $5.0(2)$ & $34.2(2)$ & n.a. \\
\hline \multicolumn{9}{|l|}{$\begin{array}{l}\text { Scottish \& } \\
\text { Newcastle (UK) }\end{array}$} \\
\hline $\begin{array}{l}\text { Kronenbourg/ } \\
\text { Danone Beer }(\mathrm{F})\end{array}$ & 2000 & $\begin{array}{l}100 \\
100 \\
\end{array}$ & $2700 \mathrm{m€}$ & n.a & n.a & 1.8 & 11.3 & 183 \\
\hline $\begin{array}{l}\text { Central de Cervejas } \\
\text { (P) }\end{array}$ & $\begin{array}{l}2002 / \\
2003\end{array}$ & $\begin{array}{l}100 \\
100\end{array}$ & $828 \mathrm{~m} €$ & 2.7 & n.a. & 3.3 & 11.4 & 251 \\
\hline $\begin{array}{l}\text { Hartwall Oyj (SF) / } \\
\text { BBH }\end{array}$ & 2002 & $\begin{array}{l}100 \\
100\end{array}$ & $2273 \mathrm{m€}$ & na. & na. & 2.81 & 10.1 & 142 \\
\hline
\end{tabular}

Sources: Thomson Financial Extel Company reports 2008, Datamonitor Company profiles 2008, various articles from the business press
(1) Data taken from table 2 of Ebneth and Theuvsen 2007:382
(2) own calculation (adjusted for $\%$ of shares owned)
(3) sales $1999=407 \mathrm{m€}$
(4) pre tax profit $2002=21$ mUS- $\$$, sales $2002=144$ mUS- $\$$
(5) Net profit 1997 293,5 mUS-\$, Sales 1997= 1930 mUS-\$ 
Table III: Large acquisitions and risk-taking: Heineken, Carlsberg, Anheuser Busch and Scottish \& Newcastle compared

\begin{tabular}{|c|c|c|c|c|c|c|}
\hline & Ownership & $\begin{array}{l}\text { Country } \\
\text { of origin } \\
\text { VoC }\end{array}$ & $\begin{array}{l}\text { Size of } \\
\text { the } \\
\text { home } \\
\text { market }\end{array}$ & $\begin{array}{l}\text { Foreig } \\
\text { n } \\
\text { presen } \\
\text { ce } \\
\text { before } \\
1990\end{array}$ & $\begin{array}{l}\text { Assess } \\
\text { ment } \\
\text { of risk- } \\
\text { taking }\end{array}$ & Risk-taking profiles \\
\hline $\begin{array}{l}\text { Heineken } \\
\text { (NL) }\end{array}$ & $\begin{array}{l}\text { Family } \\
\text { owned } \\
\text { (majority) }\end{array}$ & $\begin{array}{l}\text { Coord. } \\
\text { Market } \\
\text { Economy }\end{array}$ & Small & $\begin{array}{l}\text { Con- } \\
\text { sider- } \\
\text { able }\end{array}$ & Low & $\begin{array}{ll}- & \text { Rather low financial exposition } \\
- & \text { Well selected targets with high } \\
\text { value creation potentials } \\
\text { - } & \text { Long term orientation } \\
\text { - Strong focus on rationalization } \\
\text { modernization and integration of } \\
\text { acquired objects }\end{array}$ \\
\hline $\begin{array}{l}\text { Carlsberg } \\
\text { (DK) }\end{array}$ & $\begin{array}{l}\text { Foundation } \\
\text { owned } \\
\text { (majority) }\end{array}$ & $\begin{array}{l}\text { Coord. } \\
\text { Market } \\
\text { economy }\end{array}$ & Small & $\begin{array}{l}\text { Con- } \\
\text { sider- } \\
\text { rable }\end{array}$ & Low & $\begin{array}{ll}- & \text { Rather low financial exposition } \\
- & \text { Well selected targets with high } \\
\text { value creation potentials } \\
-\quad \text { Long term orientation } \\
-\quad \text { Strong focus on rationalization } \\
\text { modernization and integration of } \\
\text { acquired objects }\end{array}$ \\
\hline $\begin{array}{l}\text { Anheuser- } \\
\text { Busch (A-B) } \\
\text { (USA) }\end{array}$ & $\begin{array}{l}\text { Dispersed } \\
\text { stock marked } \\
\text { ownership } \\
\text { with a strong } \\
\text { management } \\
\text { influence of } \\
\text { the founding } \\
\text { family }\end{array}$ & $\begin{array}{l}\text { Liberal } \\
\text { Market } \\
\text { economy }\end{array}$ & Large & Little & High & $\begin{array}{ll}- & \text { Extremely high financial exposition } \\
- & \text { Partly uncareful selection of targets } \\
\text { (Chinese investments) } \\
\text { - } \quad \text { Little emphasis on operational } \\
\text { integration of acquired units }\end{array}$ \\
\hline $\begin{array}{l}\text { Scottish \& } \\
\text { Newcastle } \\
\text { (S\&N) } \\
\text { (UK) }\end{array}$ & $\begin{array}{l}\text { Dispersed } \\
\text { stock marked } \\
\text { ownership } \\
\text { with a strong } \\
\text { impact of } \\
\text { financial } \\
\text { markets } \\
\text { actors }\end{array}$ & $\begin{array}{l}\text { Liberal } \\
\text { Market } \\
\text { economy }\end{array}$ & Large & Little & High & $\begin{array}{ll}- & \text { Rather high financial exposition } \\
\text { - } & \begin{array}{l}\text { Partly uncareful selection of targets } \\
\text { (acquisitions in saturated markets }\end{array} \\
\text { - } & \text { Integration overload due to a } \\
\text { simultaneous acquisition of three } \\
\text { large targets } \\
\text { - Short time profit expectations and } \\
\text { unclear revenues from divestures } \\
\text { threaten the sustainability of the } \\
\text { acquisition strategy }\end{array}$ \\
\hline
\end{tabular}




\section{References}

Aguilera, R. V. and G. Jackson (2003). 'The cross-national diversity of corporate governance: Dimensions and determinants', Academy of Management Review, 28(3), pp. 447-465.

Ahuja, G. and R. Katila (2001). 'Technological acquisitions and the innovation performance of acquiring firms', Strategic Management Journal, 22, pp. 197-220.

Anheuser-Busch (various years). Annual Reports.

Axelsson, R., D. Cray, G.R. Mallory and D.C. Wilson (1991). 'Decision Style in British and Swedish Organizations: A Comparative Examination of Strategic Decision Making', British Journal of Management, 2(2) , pp. 67-79

Barkema, H. and F. Vermeulen (1998). 'International Expansion Start-Ups or Acquisition', Academy of Management Journal, 41, pp. 7-26.

Benson-Armer, R., J. Leibowitz and D. Ramachandran (1999). 'Global Beer, What's on Tap?', McKinsey Quarterly, 1, pp. 11-121.

Berlingske Tidende. (04.11.2000). Elefanten rører på sig.

Børsen (February 11, 2004). Monopolanklager og opkøb tog overskriften

Børsen (February 20, 2004). Russisk guldklump på vippen

Børsen (January 22, 2004). Opkøb styrker Carlsbergs konkurrenter

Børsen (January 23, 2004). Lukning truer Carlsberg-bryggerier

Börsen Zeitung (November 22, 2000). Scottish and Newcastle verkauft Center Parks

Börsen Zeitung (June 22, 2002). Internationaler Biermarkt schäumt hoch wie nie

Brouthers, K. D. and D. Dikova (2010). 'Acquisitions and real options: The greenfield alternative.', Journal of Management Studies. 47(6), pp. 1048-1071

Business Today (October 21, 2007). 'Ale and Hearty'. Business, 39, pp. 540-561.

Business week online, (September, 8, 2003), Heineken, http://www.businessweek.com/magazine/content/03_36/b3848012_mz044.htm (download of 11.1.2011)

Carlsberg press release (November 3, 2000). Carlsberg acquires largest Swiss brewery Feldschlösschen Carlsberg press release (November, 10, 2005). Carlsberg UK starts production of Holsten Pils

Carlsberg. (2006). Annual report.

Child, J. (1972). 'Organizational Structure, Environment and Performance: The Role of Strategic Choice', Sociology, 6(1), pp. 1-22.

Datamonitor (2008) Company Profiles 2008. Various Issues

Dieng, S., C. Dörrenbächer and J. Gammelgaard (2009). 'Subsidiary Brands as a Resource and the Redistribution of Decision Making Authority following Acquisitions', in Finkelstein, S. and C. Cooper (eds) Advances in Mergers and acquisitions, Vol. 8, pp. 141-160. Bingley: Emerald Group Publishing Limited.

Dörrenbächer, C. (2000). 'Between Global Market Constraints and National Dependencies. The Internationalisation of the World Leading Telecommunication Equipment Manufacturers 1980-1995', Transnational Corporations, 9(3), pp. 1-35.

Dunning, J.H. (1988). 'The Eclectic Paradigm of International Production: A Restatement and Some Possible Extensions', Journal of Business Studies, Spring, pp. 1-31.

Dunning, J.H. (2009). 'Location and the Multinational Enterprise: A Neglected Factor?', Journal of Business Studies, 40(1), pp. 5-19.

Ebneth, O. and L. Theuvsen (2007). 'Large Mergers and Acquisitions of European Brewing companies - Evident Study Evidence on Value Creation'. Agrobusiness, 23(3), pp. 377-406.

Economist (June 5, 2004). The beers are on Anheuser; Beer in China.

Eisenhardt, K., (1989). 'Building theories from case study research', In: Academy of Management Review, 14, 4, pp. 532-550.

Eliassov, R. (2002). Bravo Heineken! The impact of foreign direct Investment in the case of the Beer Industry in Russia, MSc-Thesis at the faculty of low, Leiden University (mimeo: 127pp)

Elshof, P. (2004). ,Zukunft der Brauwirtschaft . Internationalisierungsstrategien der Brauereikonzerne‘, Düsseldorf: Edition der Hans-Böckler Stiftung.

Elshof, P. (2005). Heineken N.V. Company Profile, mimeo, Food world research \& consultancy.

Fernández, Z. and M.J. Nieto (2006). 'Impact of ownership on the international involvement of SMEs', Journal of International Business Studies, 37, pp. 340-351.

Ferner, A. (1997). 'Country of Origin Effects and Human Resource Management in Multinational Companies', Human Resource Management, 7, pp. 19-37. 
Filatotchev, I. and C. Nakajima (2010), 'Internal and External Corporate Governance: An Interface between and organization and its environment', British Journal of Management, 21(3), pp. 591-606.

Financial Times (November 21, 2007). S\&N hits out at Carlsberg offer

Financial Times (July 2, 2003). S\&N held back by weak UK and France

Financial Times (May 17, 2004). Anheuser puts Chinese brewers in a spin

Financial Times (May 3, 2005). Heineken shows thirst for central Europe

Financial Times (June 29, 2005). Anheuser still finding a taste for Harbin

Financial Times (August 10, 2005). Russia lifts UK`s top brewer despite fall in European sales

Financial Times (May 14, 2003). S\&N in $€ 342 \mathrm{~m}$ Portuguese brewing deal

Financial Times (March 21, 2000). Scottish \& Newcastle

Financial Times (May 3, 2000). Scottish \& Newcastle

Financial Times Deutschland (May 5, 2003). Heineken kauft größte Brauerei Österreichs

Financial Times Europe (October 18, 2007). Stalking S\&N

Frankfurter Allgemeine Zeitung (March 1, 2000). Britische Brauerei Scottish \& Newcastle verkauft Center Parcs

George, A. and A. Bennett (2005). Case studies and theory development in the social sciences. Cambridge: MIT Press.

Geppert, M. and B. Martens (2008). Corporate Financing, Management and Organization: An AngloGerman Comparison'. In Bluhm, K. and Schmidt, R. (eds), Change in SMEs: Towards a New European Capitalism?, Basingstoke: Palgrave.

Geppert, M., D. Matten and K. Williams (2003). 'Change Management in MNCs: How Global Convergence Intertwines with National Diversities', Human Relations, 56(7), pp. 807-838.

Glamann, K. (1997). Vores øl: og hele verdens: Carlsberggruppen siden 1970. Copenhagen. Gyldendal, 1997.

Gomes-Casseres, B. (1996), The Alliance Revolution: The new shape of business rivalry. Cambridge: Harvard University Press.

Hall, P.A. and D. Soskice (2001). Varieties of Capitalism: The Institutional Foundations of Comparative Advantage. Oxford: Oxford University Press

Heineken (2007). Annual report.

Heineken (2009). Annual report.

Heracleous, L. (2001). 'When local beat global: The Chinese beer industry', Business Strategy Review, 12(3), pp. 37-45.

Hoffmann, W. H. and W. Schaper-Rinkel (2001). 'Acquire or ally? - A strategy framework for deciding between acquisition and cooperation.', Management International Review, 41, pp. 131-159.

Hofstede, G. (1980). Culture's consequences: International differences in work-related values. Newbury Park, CA: Sage.

Houman-Andersen, P. and M.A. Skaates (2004). Ensuring Validity in Qualitative International Business Research. In Marschan-Piekkari, R. and C. Welch (eds): Handbook of qualitative research methods for international business. Cheltenham/Northampton: Edward Elgar, pp. 464-485.

Iversen, M. J. and A. Arnold (2008). 'Carlsberg: regulation of the home market and international expansion'. In Fellman, S., M. Iversen, H. Sjögren, and L. Thue (eds), Creating Nordic capitalism : The business history of a competitive periphery, pp. 365-391, Basingstoke: Palgrave Macmillan.

James, H. (2008). 'Family Values or Crony Capitalism?', Capitalism and Society, 3, pp. 1-28. Journal of Economics, 23, pp. 127-150.

Jyllands Posten (June 1, 2000). Carlsberg strømliner sin bestyrelse

Jyllands Posten (August 4, 2004). Bryggeri: Feldschlösschen er Carlsbergs lille guldæg.

Koudal, P. and D. Engel (2007), Globalization and emerging markets. In Lee, H.L. and C-Y. Lee (eds), Building Supply Chain Excellence in Emerging Economies, pp. 37-64. New York, NY: Springer.

Larsson, R. and S. Finkelstein (1999). 'Integrating strategic, organizational, and human resource perspectives on mergers and acquisitions: A case survey of synergy realization', Organization Science, 10(1), pp. 1-26.

Lewis, C. (2001). 'The future of British brewing: strategies for survival' British Journal of Management, 10(3), pp. 151-161. 
Li, J., J. Y. Yang and D. R. Yue (2007). 'Identity, community, and audience: How wholly owned foreign subsidiaries gain legitimacy in China'. Academy of Management Journal, 50(1), pp. 175-190.

Lockett, A., J. Wiklund, P. Davidsson and S. Girma (2011). 'Organic and Acquisitive Growth: ReExamining and Extending the Penrose's Growth Theory'. Journal of Management Studies, 48(1), pp. 48-74.

Lopes, T. da Silva (2007). Global Brands: The Evolution of Multinationals in Alcoholic Beverages. Cambridge: Cambridge University Press.

Marketing Week (June 28, 2007). Carlsberg brings in Polish pilsner brand on draught.

Meyer, K. and Y.T.T. Tran (2006). 'Market penetration and acquisition strategies for emerging economies'. Long Range Planning, 39(2), pp. 177-197.

Morosoni, P., Shane, S., and Singh, H. (1998). 'National cultural difference and cross-border acquisition performance'. Journal of International Business Studies, 29(1), pp. 137-158.

Narula, R. (2000). Explaining 'Inertia' in R\&D Internationalization: Norwegian Firms and the Role of Home Country Effects. Working Paper, Centre for Technology, Innovation and Culture, University of Oslo.

Noorderhaven, N.G. and A.W.K. Harzing (2003). 'The "Country-Of-Origin Effect" in multinational corporations: sources, mechanisms and moderating conditions'. Management International Review, 43, special issue 2, pp. 47-66.

Nooteboom, B. (1999). 'Innovation, learning and industrial organisation'. Cambridge Journal of Economics, 23(2), pp. 127-150.

North, D. (1990). Institutions, Institutional Change and Economic Performance, Cambridge: Cambridge University Press.

Paruchuri, S., A. Nerkar and D. C. Hambrick (2006). 'Acquisition integration and productivity losses in the technical core: Disruption of inventors in acquired companies'. Organization Science, 17(5), pp. 545-562.

Penrose, E. (1959). The Theory of the Growth of the Firm. Oxford: Oxford University Press. resource perspectives on mergers and acquisitions: A case survey of synergy realization'. Organization Science, 6(1), pp. 76-91.

Roberts, J. (2004). The Modern Firm. Oxford: Oxford University Press.

Rugman, A. M. (2005). The Regional Multinationals, MNEs and "Global" Strategic Management Cambridge: Cambridge University Press.

Salancik, G. and J. Meindl (1984). 'Corporate attributions as strategic illusions of management control?'. University at Buffalo, State University of New York.

Schweizer, L. (2005). 'Organizational integration of acquired biotechnology companies into pharmaceutical companies: The need for a hybrid approach, Academy of Management Journal, 48(6), pp. 1051-1074.

Scott, J. (1990). A matter of record. Documentary Sources in Social Research Cambridge: Polity press

Scottish and Newcastle (2002). Annual Report and Accounts, various issues

Sorge, A. (2005). The Global and the Local, Oxford: Oxford University Press.

Teece, D. J., G: Pisano and A. Shuen (1997). 'Dynamic capabilities and strategic

The Grocer (March 11, 2006). Poland scores a hat-trick of lagers.

The Grocer (October 20, 2007). S\&N may be forced to accept Carlsberg-Heineken takeover.

The Guardian, (June 11, 1999). Cruzcampo stake sold to Heineken.

The St. Petersburg Times, (February 2, 2002). Heineken Seals \$400M Bravo Deal.

Thomson Financial Extel Company report (2008). Various issues.

Trautwein, F. (1990). 'Merger motives and merger prescriptions', Strategic Management Journal, 18, pp. 283-295.

UNCTAD (2010). World investment report 2010. Investing in a low carbon Economy, New York and Geneva: United Nations.

Vermeulen, F. and H. Barkema (2002): 'Pace, Rhythm, and Scope: Process Dependence in Building a Profitable Multinational Corporation'. Strategic Management Journal, 23, pp. 637-653.

Wall Street Journal (June 17, 2008).Chilling a deal for Bud

Whitley, R. (1999). Divergent Capitalisms: The Social Structuring and Change of Business Systems. Oxford: Oxford University Press.

Whitley, R. (2001). How and Why are International Firms Different? The Consequences of Crossborder Managerial Coordination for Firm Characteristics and Behaviour. In: Morgan et al. (2001). Morgan, G., P. Kristensen and R. Whitley, R. (eds) (2001). The Multinational Firm. Organizing across Institutional and National Divides, pp. 27-68. Oxford: Oxford University Press. 
Whitley, R. (2007), Business Systems and Organizational Capabilities: The institutional structuring of competitive competences. Oxford: Oxford University Press.

Williamson, O. E. (1975). Market and Hierarchies - Analysis and Antitrust Implications. The Free Press, New York

Zahra, S.A. (2003). 'International expansion of U.S. manufacturing family businesses: the effect of ownership and involvement', Journal of Business Venturing, 18(4), pp. 495-512.

${ }^{\mathrm{i}}$ Coordinated market economies score rather low on Hofstedes individualism scale (e.g. Germany: 68, France: 71, Denmark: 74, the Netherlands: 80) whereas liberal market economies score high here (UK: 89, AUS 90, US 91). See http://www.geerthofstede.com/hofstede dimensions.php?culture 1=34\&culture2=23\#compare (accessed 15.June 2011)

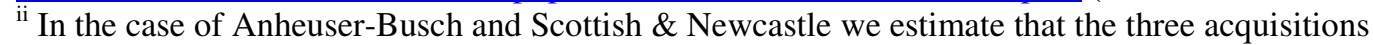
considered cover more than $80 \%$ of the increase in multinationality (measured as increase in foreign sales to total sales). In the case of Heineken and Carlsberg we estimate coverage of at least 50\%.

${ }^{\text {iii }}$ Based on the screening of 140 major newspapers and journals worldwide, the HWWA press archive (based in Hamburg/Germany) contains press information on the largest multinational corporations in the world from the early 1980ies till 2005.

iv Media reports indicate: a) that the sale of Center Parcs - the firms leisure business - led to significant increases of S\&N's share price of up to 7\% (Frankfurter Allgemeine Zeitung, March 1, 2000) and b) that the firm needed these funds and stock market gains in order to realise 'its future strategy as an international brewer' (Financial Times, May 3, 2000).

${ }^{\mathrm{v}}$ In Table I it can be seen that Heineken and Carlsberg have a lower reliance on capital markets for their financing than A-B and S\&N. Indeed in the case of S\&N if a four year average is taken the loan capital raised rises to $63.11 \%$ and bank loans drop to $25.39 \%$ as during the four years from 2004-2007 they depended more on capital financing from the markets. The greater dependence on bank loans reflects the long term relationships with local banks by Heineken and Carlsberg typical for coordinated market economies. 